\title{
Bostricobranchus digonas Abbott (Ascidiacea, Molgulidae) in Paranaguá Bay, Paraná, Brazil. A case of recent invasion? ${ }^{1}$
}

\author{
Rosana Moreira da Rocha ${ }^{2}$
}

\begin{abstract}
Bostricobranchus digonas Abbott, 1951 was discovered by dredging

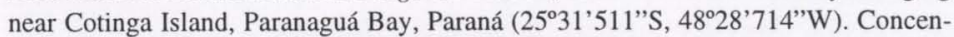
trated in a small area $1.5 \mathrm{~m}$ deep, the animals were collected by a Van Veen device. All sizes from $3 \mathrm{~mm}$ up to $2 \mathrm{~cm}$ in body diameter were recovered. This is the first report of a species of this genus in the South Atlantic and its occurrence is discussed.

KEY WORDS. Ascidiacea, Molgulidae, Bostricobranchus, nonindigenous fauna
\end{abstract}

Bostricobranchus digonas Abbott, 1951 is an estuarine species, to date, only described in Florida, USA. Here, the second occurrence of this species is reported in southeastern Brazil. Many individuals were collected in Paranaguá estuary, but surprisingly subsequent sampling failed to find more individuals.

Marine species invasions have received much concern in recent years (CARLTON \& GELLER 1993; LAMBERT 2001 for a review on ascidians) and one of the most difficult aspects in studying the consequences of these invasions is to determine when new species arrive in any region. This paper describes morphological characters of a Bostricobranchus Traustedt, 1883 population showing that the individuals are very similar to the population of $B$. digonas from Florida, to which it is thought conspecific. Also, the presence of an important harbor for petroleum tanking ships nearby suggests that this is a possible recent introduction.

\section{MATERIAL AND METHODS}

Specimens were collected in August 2000 by a Van Veen device at Cotinga

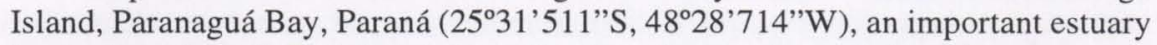
in southern Brazil. Salinity at the collecting site was 31 and the substrate was a mixture of sand and mud, with a low-tide depth of $1.5 \mathrm{~m}$. Vouchers were deposited in the Collection of the Departamento de Zoologia, Universidade Federal do Paraná, under the codes MOL 09, MOL 10, MOL 11, MOL 12, MOL 13, and permanent slides MOL 1-12, MOL 1-13, MOL 1-14, MOL 1-14, MOL 1-15.

Dissecting techniques and the preparation of permanent slides followed MONNIOT \& MONNIOT (1972) and RODRIGUES et al. (1998).

1) Contribution number 1277 from the Zoology Department, Universidade Federal do Paraná.

2) Universidade Federal do Paraná, Departamento de Zoologia, CP 19020, 81531-980, Curitiba, Paraná, Brazil, E-mail: rmrocha@ @io.ufpr.br 


\section{Molgulidae Lacaze-Duthiers, 1877}

\section{Bostricobranchus Traustedt, 1883 \\ Bostricobranchus digonas Abbott, 1951}

Fig. 1

Animals are very round with a maximum body diameter of $22 \mathrm{~mm}$ excluding the siphons. The tunic is thin, completely transparent and gelatinous with a thin layer of sediment on the surface, except by the siphons and the upper part of the body. Very thin hair-like processes project from the lower part of the body and also retain sand grains. Smaller animals have longer threads.

Siphons are long and very close to each other. There are no depressions or grooves at their base and animals did not contract the siphons when taken from the substrate. Even animals that were not anesthetized maintained elongated siphons after fixation. The oral siphon has six lobes, with pigmented spots between them. The atrial siphon has four lobes with a small square aperture.

The mantle is also transparent and uncolored. Strong muscles are present only on the siphons. The circular muscles lay from the top to the base of the siphons and the longitudinal ones extend slightly further than the last circular ones. Very slender and short parallel bands extend across each side of the midventral region.

Oral tentacles have a very wide base, forming a membrane from which other wide membranes appear on each side, only the edge of which is ramified. There are 14 to 23 tentacles of four sizes, not correlated with the size of the animal; animals with fewer tentacles had four of the largest size and animals with greater numbers had six. The orifice of the dorsal tubercle is $\mathrm{C}$-shaped with the opening directed toward the left. Large specimens have the horns of the $\mathrm{C}$-shape incurved. The neural gland lies to the right side of the ganglion. The dorsal lamina is smooth, extending beyond the oesophageal aperture on its left to the end of the digestive gland. It is widest at the oesophageal aperture.

The branchial sac has no folds, but contains eight wide longitudinal vessels on the right side and seven on the left (small animals have seven vessels on both sides). Five transversal vessels are present in each side. The anterior portion of the branchial sac is without any stigmata. Infundibula are made of two long and narrow stigmata forming a double spiral. Raised infundibula in old animals are finger-like and form brooding sites in the atrial cavity for two or three embryos. Even in small animals of $6-7 \mathrm{~mm}$ it is not possible to see the longitudinal rows of primary infundibula under the longitudinal vessels. Large animals have 13-16 infundibula in each mesh, while small animals have 4-6. The endostyle is very long and wide.

The oesophagus is short, wide and curved. The stomach is oval shaped, without any folds on the wall. The digestive gland covers only the right wall of the stomach with a larger portion in the cardiac region and a smaller portion in the middle of it. Its walls are longitudinally folded and twisted near the distal end to form the small portion. The intestine forms a closed primary loop and a wide and short secondary loop. The anus is bordered by two lips which curve outwards, with many small lobes on the edge. One large animal had 26 lobes. 


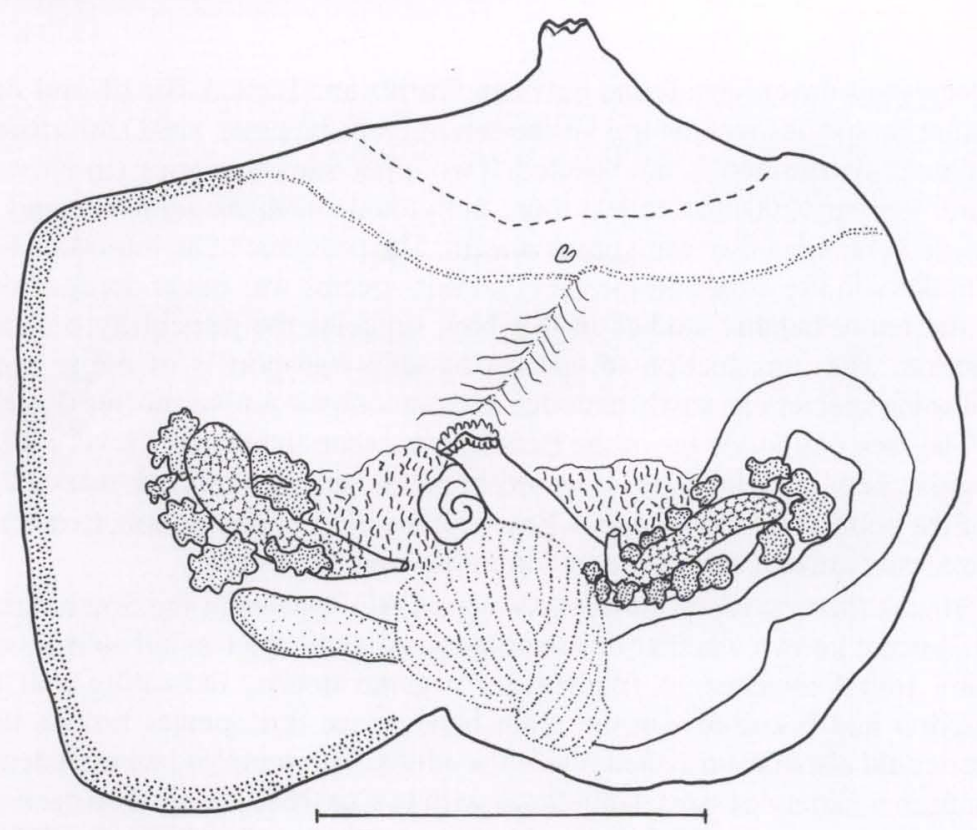

Fig. 1. Dissected animal without the branchial sac. Scale $=1 \mathrm{~cm}$.

Gonads are present on both sides. The right ovary is flask-shaped, elongated, almost twice the size of the renal sac, which is also elongated and displaced dorsally, touching the digestive gland. Testicular lobes surround the ovary, especially at its blind end. Testicular lobes form groups with common sperm ducts that merge. On the left side, only the more distal part of the ovary and some of the lobes of the testes are inside the intestinal loop, most of them are on the dorsal branch of the loop. In old animals there is a membrane inside the body wall, near the apertures of both gonads. From this membrane, there are numerous filiform projections that seem to prevent the eggs from leaving the body through the atrial siphon after leaving the oviduct. In the atrial cavity, free or inside the infundibula, there are round anural embryos and star embryos, which are in the process of metamorphosis (SWALLA \& JEFFERY 1992).

Animals as small as one centimeter had developed ovaries but very few testicles, and no embryos in the atrial cavity. Very small juveniles of 1-2 mm were found attached on algae and other filaments, without any sand grain on the tunic. It seems that they first attach on a substrate free of sand and only burrow afterwards.

\section{DISCUSSION}

Bostricobranchus digonas was first described from a population living in the Peace River estuary, Charlotte Harbor, Florida (Аввотт 1951). The specimens from Paranaguá Bay agree very well with the description made by Abbott, except that none of the individuals showed contracted siphons and the larger animals have eight, instead of seven, longitudinal vessels on the right side of the branchial sac. 
This species has never been found between Florida and Paraná, Brazil, and since it is an estuarine species with anural larvae (SWALLA \& JEFERRY 1992) this disrupted geographical distribution is unexpected. Two other sampling trips (in November 2000 and February 2001) to collect more individuals from the same site and other sites inside Paranaguá Bay were unsuccessful. The presence of an important harbor for oil tankers in the area, and the fact that this species was never dredged during any of the many benthic studies in this bay, suggests the possibility of a recent introduction. The introduction of species by ship transport is of major concern because some species can easily dislodge and outcompete native species (LAMBERT 2001). The lack of knowledge of the Brazilian ascidian fauna make it very difficult to recognize new introductions. It would be interesting to compare isozymes and DNA of the population in Paranaguá Bay with the Florida population, to determine how close they are and estimate how long they have been apart.

This is the first report of a Bostricobranchus species in the South Atlantic. Though it is not known whether this population is established, small animals of 3-4 $\mathrm{mm}$ were found attached to filamentous organic debris, indicating that some reproduction had occurred. On the other hand, since this species broods larvae, juveniles could also have traveled inside the adults. The samples had high densities of animals in a variety of sizes, sometimes with two or three attached on each other.

There are only two other known congeneric species: B. pillularis (Verrill, 1871 ) and B. septum Monniot, 1978. The first is from the Atlantic coast of North America and has only one gonad on its left side (VAN NAME 1945); the second one was found in high latitudes of the Indian Ocean, is smaller from B. digonas and has only six longitudinal vessels on each side of the branchial sac (MONNIOT 1978).

KOTT (1985) proposed the synonymy of Bostricobranchus and Eugyra Alder \& Hancock, 1870 because the only difference she recognized between the two genera was the presence, in the former, of accessory infundibula that increase in size and number during development, so that it is almost impossible to distinguish the primary infundibula in large specimens. KOTT (1985) argues that some Eugyra also have accessory infundibula, and therefore this character should not be used to indicate generic distinction. On the other hand, VAN NAME (1945) comments that "the remarkable development of the accessory infundibula in the present group (Bostricobranchus) represents a distinct advance step in the evolution and specialization of the branchial sac beyond that characteristic of Eugyra which seems worthy of recognition in classification". Before some one makes an extensive revision of the two genera I agree with VAN NAME (1945) and prefer to maintain both genera apart. Further, even small specimens of $B$. digonas in Paranaguá Bay have many accessory infundibula and no recognizable primary infundibula indicating that this could be a stable character and not just a matter of growth.

ACKNOWLEDGEMENTS. I thank the undergraduate students of the Marine Biology Course, which found the specimens in a field trip, and the Setor de Ciências Biológicas from Universidade Federal do Paraná who financed this trip. I also thank Dr. Henry L. Spach, Dr. Pedro Martinez Arbizu, Biol. Paulo Corgosinho and Biol. Rafael Metri, which helped looking for other

Revta bras. Zool. 19 (Supl. 1): 157 - 161, 2002 
populations of Bostricobranchus digonas. Dr. B. Swalla helped me to understand the star shaped embryos; Dr. P. Kott gently sent me a copy of Dr. Abbott's paper; Dr. J. Roper reviewed the English text, to all of them I am indebted.

\section{REFERENCES}

Аввотт, D.P. 1951. Bostrichobranchus digonas, a new molgulid ascidian from Florida. Jour. Wash. Acad. Sci. 41: 302-307.

CARLton, J.T. \& J.B. GeLler. 1993. Ecological roulette: the global transport of nonindigenous marine organisms. Science 261: 78-82.

KotT, P.M. 1985. The Australian Ascidiacea. Part I, Phlebobranchia and Stolidobranchia. Mem. Queensl. Mus. 23: 1-440.

LAMBERT, G. 2001. A global overview of ascidian introductions and their possible impact on the endemic fauna, p. 249-257. In: H. SAWADA; H. YoKoSAWA \& C.C. LAMBERT(Eds). The Biology of Ascidians. Tokyo, Springer Verlag, XXVII+470p.

Monniot, C. \& F. Monniot. 1972. Clé mondiale des genres d'Ascidies. Arch. Zool. Exp. Gen. 113 (3): 311-367.

Rodrigues, S. A; R.M. Rocha \& T.M.C. Lotufo. 1998. Guia Ilustrado para a Identificação das Ascídias do Estado de São Paulo. São Paulo, FAPESP, Universidade de São Paulo, 190p.

SWALLA, B.J. \& W.R. JEFFERY. 1992. Vestigial brain melanocyte development during embryogenesis of a viviparous anural ascidian. Dev. Growth Differ. 34:17-25.

van Name, W.G. 1945. The North and South American ascidians. Bull. Amer. Mus. Nat. Hist. 84: $1-476$.

Received in 21.IX.2001; accepted in 16.VI.2002. 